\title{
Suitability of some faba bean cultivars for intercropping with sugar beet
}

\author{
Ahmed M. Sheha, Amr S. Shams and Yasser E. El-Ghobashi \\ Crop Intensification Res. Dep., Field Crops Res. Inst., Agric. Res. Center, Egypt. \\ Received: 14 April 2020/Accepted 15 June 2020 / Publication date: 30 June 2020
}

\begin{abstract}
Field experiment was carried out at Gemmiza Agricultural Research Station, Agricultural Research Center, El-Gharbia governorate, Egypt during 2016/2017 and 2017/2018 seasons to determine the most suitable faba bean cultivar for intercropping with sugar beet in order to increase land equivalent ratio and farmer's benefit. Four faba bean cultivars (Sakha 1, Misr 1, Giza 843 and Giza 3 'Improved') were intercropped to sugar beet in a randomized complete block design (RCBD) with three replications. Sole cultures of sugar beet and faba bean were used for calculating competitive relationships and net return. Sugar beet plants grown with faba bean cultivar Misr 1 had higher total chlorophyll content and leaf area and better sugar beet root yield and its attributes than those intercropped with the other faba bean cultivars in both seasons. Faba bean plants of Giza 843 grown with sugar beet had higher total chlorophyll content and leaf area compared with the other cultivars in both seasons. In addition, Giza 843 had higher number of branches and pods plant ${ }^{-1}$, number of seeds pod ${ }^{-1}, 100$-seed weight, seed yield plant $^{-1}$ and seed and straw yields fed ${ }^{-1}$ than the other faba bean cultivars in the two seasons. Land equivalent ratio and relative crowding coefficient were above 1.00 indicating intercropping advantages for all treatments. The value of aggressivity of sugar beet was negative for all treatments indicating that sugar beet was dominated component in the present study. Intercropping faba bean cultivar Misr 1 with sugar beet was more profitable to farmers than the rest of tested cultivars and the sole culture of sugar beet for gross income and net return.
\end{abstract}

Keywords: Beta vulgaris L., Vicia faba L., Land equivalent ratio, Net return.

\section{Introduction}

In general, Egypt faces many problems that affect productivity of crops and sugar crops in particular where sugar is a national demand. One of them is a severely competition between sugar crops and the other winter crops for land, water, light and nutrients according to production costs and lower net returns. This increases the need to maximize land usage and improve farmer's income. Sugar beet (Beta vulgaris L.) crop has been introduced in the early 1980s to help, besides sugarcane in fulfilling the gap between sugar production and consumption (Abdel-Motagally and Metwally, 2014).

On the other hand, the local production of faba bean (Vicia faba L.) is still below the country consumption. Increasing faba bean production is a major target to meet the increasing demand, since faba bean constitutes a major part of the diet of Egyptian people (Zeidan, 2002). Also, it's important for soil fertility, human nutrition as a good source of vegetarian protein, animal feeding and industry purposes (Sharaan et al., 2004). Therefore, increasing faba bean production is one of the major targets of the agricultural policy and can be fulfilled through increasing the cultivated area, using high productive varieties. Unfortunately, sugar beet cultivated area reached about 559,744 fed (one fed = $4200 \mathrm{~m}^{2}$ ) in 2016/2017 season, while cultivated area of faba bean reached about 87,808 fed in 2016/2017 season, respectively, (Bulletin of Statistical Cost Production and Net Return, 2018).

Accordingly, scientific efforts are continually looking for different ways to increase productivity of faba bean without significant change in sugar beet area. It is known that output improvement in cropping systems must be related to the better use of resources especially water and light. Intercropping is inexpensive strategy for better use of resources especially water and light, which has been recognized as a potentially benefited technology for increased crop production and consequently increasing the net income per unit area. Over the past few decades, increasing attention has been given to intercropping in Egypt. So, it is feasible to augment the acreage of the legume crop by intercropping with sugar beet. In this concern, several studies have reported that intercropping faba bean with sugar beet is more

Corresponding Author: Amr S. Shams, Crop Intensification Res. Dep., Field Crops Res. Inst., Agric. Res. Center, Egypt. E-mail: dr_amrshams@yahoo.com 
productive than the individual sole crops (Farghaly et al., 2003; Mohammed et al., 2005; Gadallah et al., 2006; Aboukhadra et al., 2013; Salama et al., 2016 and El-Ghobashi and Eata, 2020).

Generally, reducing density of faba bean plants may lead to minimize the intra and inter competition of both crops, which increased efficiency of solar radiation utilized, by sugar beet, and in turn high conversion of light energy to chemical energy and consequently high accumulation of dry matter. If faba bean plant density is too high, plants compete with each other for resources and low yield was realized under intercropping with sugar beet, (Mohammed et al., 2005). Accordingly, intercropping culture might be led to the inactivation or impairment of the chlorophyll containing reaction centers of the chloroplasts, which reflected on insufficient ATP for carbon fixation and carbohydrate biosynthesis (Shao et al., 2014). Hence, the target of this research is increasing plant density of intercropped faba bean in sugar beet fields to reach $25 \%$ of faba bean sole planting where previous technical recommendations of intercropping faba bean with sugar beet indicated that faba bean plant density should not be exceeded $12.5 \%$ of faba bean sole planting in Egypt. Thus, selecting the suitable faba bean cultivar for intercropping with sugar beet could play important role for enhancing farmer's income. Field bean cultivars markedly differed in their growth characteristics and potential yield. In this connection, Mohamed and El-Abbas (2005) concluded that Sakha 1 cultivar surpassed Giza 3 and Giza 2 cultivars in seed weight per plant, 100-seed weight and seed yield per fed. However, Kandil et al. (2011) found that Giza 716 cultivar significantly exceeded other studied cultivars (Sakha 1 and Giza 3 ) in plant height, numbers of branches and pods per plant, number of seeds per pod, seed yield per plant, 100-seed weight and seed yield per ha. Moreover, Mohamed et al. (2018) showed that faba bean cultivar Sakha 1 had higher values of seed yield and its attributes than Masr 3. Thus, the objective of this investigation was to determine suitable faba bean cultivar for intercropping with sugar beet to increase land equivalent ratio and profitability.

\section{Materials and Methods}

A field experiment was carried out at Gemmiza Agricultural Research Station, Agricultural Research Center, (Lat. 30 47' 27" N, Long. 30 59' 53" E, $22 \mathrm{~m}$ above sea level), Egypt during 2016/2017 and 2017/2018 seasons to determine the suitable faba bean cultivar for intercropping with sugar beet to increase land equivalent ratio and farmer's benefit. Four faba bean cultivars (Sakha 1, Misr 1, Giza 843 and Giza 3 'Improved') were intercropped to sugar beet in a randomized complete block design (RCBD) with three replications. Plot area was $28.8 \mathrm{~m}^{2}$. Each plot consisted of 6 raised beds $(4.0$ $\mathrm{m}$ long and $1.2 \mathrm{~m}$ wide). Sole cultures of sugar beet and faba bean cultivars (as recommended) were used for calculating competitive relationships and net return. Sugar beet seeds were sown on both sides of all beds ( $1.2 \mathrm{~m}$ width) distanced at $20 \mathrm{~cm}$ between hills (one plant/hill) to give $100 \%$ of the sole culture. Faba bean cultivars were sown on only one row in the middle of each bed at $20 \mathrm{~cm}$ apart between hills (two plants hill ${ }^{-1}$ ) to give $25 \%$ of sole culture density. Sole cultures of sugar beet and faba bean cultivars were sown as recommended.

Maize was the preceding summer crop in both seasons. Calcium super phosphate $\left(15.5 \% \mathrm{P}_{2} \mathrm{O}_{5}\right)$ at rate of $150 \mathrm{~kg} \mathrm{fed}^{-1}$ was applied during soil preparation in the two seasons. Sugar beet was sown on October $3^{\text {rd }}$ and $10^{\text {th }}$ while faba bean was sown 30 days after sugar beet sowing. In the two seasons, nitrogen fertilizer was added for sugar beet at a rate of $80 \mathrm{~kg} \mathrm{~N}$ fed $^{-1}$ as ammonium nitrate $(33.5 \% \mathrm{~N})$. Seeds of faba bean cultivars were inoculated with Rhizobium leguminosarum before seeding it and gum Arabic was used as a sticking agent. Recommended cultural practices for each crop were implemented as provided by the Egyptian Ministry of Agriculture.

\section{The studied traits \\ I. Sugar beet}

After 120 days, random samples of five sugar beet plants were taken from each plot to determine total chlorophyll content $\left(\mathrm{mg} \mathrm{g}^{-1}\right)$ and total leaf area plant ${ }^{-1}\left(\mathrm{~m}^{2}\right)$. According to the method of Wettstein (1957), total chlorophyll content in sugar beet leaves was determined by the General Organization for Agricultural Equalization Fund, ARC, Giza, Egypt. The punch method of Watson and Watson (1953), was followed to measure plant leaf area.

At harvest, ten plants from each plot were randomly taken to measure: root length $(\mathrm{cm})$, root diameter $(\mathrm{cm})$ and root weight plant ${ }^{-1}(\mathrm{~kg})$. Top fresh weight and root yield fed ${ }^{-1}(\mathrm{ton})$ were recorded on 
plot basis. Total soluble solids percentage (TSS \%) was measured by the refractometer set according to A.O.A.C. (1990). Sucrose \% was estimated by using sucrometer set. Sugar yield fed ${ }^{-1}$ (ton) was calculated as follows:

$$
\text { Sugar yield } \mathrm{fed}^{-1}(\text { ton })=\text { Root yield fed }{ }^{-1}(\text { ton }) \times \text { Sucrose } \%
$$

\section{Faba bean}

Random samples of five faba bean plants were taken from each plot 90 days after planting to determine total chlorophyll content $\left(\mathrm{mg} \mathrm{g}^{-1}\right)$ and total leaf area plant ${ }^{-1}\left(\mathrm{~cm}^{2}\right)$.

At harvest, ten guarded plants from each plot were taken to measure: plant height $(\mathrm{cm})$, number of branches and pods plant ${ }^{-1}$, number of seeds pod ${ }^{-1}, 100$-seed weight $(\mathrm{g})$ and seed yield plant ${ }^{-1}(\mathrm{~g})$. Straw and seed yields fed ${ }^{-1}$ were recorded on plot basis.

\section{Competitive relationships}

\section{Land equivalent ratio (LER)}

LER defines as the ratio of area needed under sole cropping to one of intercropping at the same management level to produce an equivalent yield (Mead and Willey, 1980). It is calculated as follows: $\mathrm{LER}=\left(\mathrm{Y}_{\mathrm{ab}} / \mathrm{Y}_{\mathrm{aa}}\right)+\left(\mathrm{Y}_{\mathrm{ba}} / \mathrm{Y}_{\mathrm{bb}}\right)$, Where $\mathrm{Y}_{\mathrm{aa}}=$ Pure stand yield of crop a (sugar beet), $\mathrm{Y}_{\mathrm{bb}}=$ Pure stand yield of crop $b$ (faba bean), $Y_{a b}=$ Intercrop yield of crop a (sugar beet) and $Y_{b a}=$ Intercrop yield of crop $\mathrm{b}$ (faba bean).

\section{System productivity index (SPI)}

SPI was calculated as (Odo, 1991). It was calculated as follows:

$\mathrm{SPI}=\left[\left(\mathrm{S}_{\mathrm{A}} / \mathrm{L}_{\mathrm{B}}\right) \times \mathrm{L}_{\mathrm{b}}\right]+\mathrm{S}_{\mathrm{a}}$, where $\mathrm{S}_{\mathrm{A}}$ and $\mathrm{L}_{\mathrm{B}}$ are the yield of sugar beet and faba bean in sole cropping, $S_{a}$ and $L_{b}$ are the yield of sugar beet and faba bean in intercropping

\section{Relative crowding coefficient (RCC)}

$\mathrm{RCC}$, which estimates the relative dominance of one species over the other in the intercropping system (De Wit, 1960) was calculated as follows: $\mathrm{K}=\mathrm{K}_{\mathrm{a}} \times \mathrm{K}_{\mathrm{b}}, \mathrm{K}_{\mathrm{a}}=\mathrm{Y}_{\mathrm{ab}} \times \mathrm{Z}_{\mathrm{ba}} /\left[\left(\mathrm{Y}_{\mathrm{aa}}-\mathrm{Y}_{\mathrm{ab}}\right) \times \mathrm{Z}_{\mathrm{ab}}\right] ; \mathrm{K}_{\mathrm{b}}$ $=\mathrm{Y}_{\mathrm{ba}} \times \mathrm{Z}_{\mathrm{ab}} /\left[\left(\mathrm{Y}_{\mathrm{bb}}-\mathrm{Y}_{\mathrm{ba}}\right) \times \mathrm{Z}_{\mathrm{ba}}\right]$, Where $\mathrm{Y}_{\mathrm{aa}}=$ Pure stand yield of crop a (sugar beet); $\mathrm{Y}_{\mathrm{bb}}=$ Pure stand yield of crop $b$ (faba bean); $Y_{a b}=$ Intercrop yield of crop a (sugar beet); $Y_{b a}=$ Intercrop yield of crop $b$ (faba bean); $Z_{a b}=$ The respective proportion of crop $a$ in the intercropping system (sugar beet); $Z_{b a}=$ The respective proportion of crop $b$ in the intercropping system (faba bean).

\section{Aggressivity (A)}

Aggressivity represents a simple measure of how much the relative yield increase in one crop is greater than the other in an intercropping system (Willey, 1979) was calculated as follows: $A_{a b}=\left[Y_{a b} /\right.$ $\left.\left(\mathrm{Y}_{\mathrm{aa}} \times \mathrm{Z}_{\mathrm{ab}}\right)\right]-\left[\mathrm{Y}_{\mathrm{ba}} /\left(\mathrm{Y}_{\mathrm{bb}} \times \mathrm{Z}_{\mathrm{ba}}\right)\right] ; \mathrm{A}_{\mathrm{ba}}=\left[\mathrm{Y}_{\mathrm{ba}} /\left(\mathrm{Y}_{\mathrm{bb}} \times \mathrm{Z}_{\mathrm{ba}}\right)\right]-\left[\mathrm{Y}_{\mathrm{ab}} /\left(\mathrm{Y}_{\mathrm{aa}} \times \mathrm{Z}_{\mathrm{ab}}\right)\right]$.

\section{Economic evaluation}

It was calculated by determining the net return of intercropping culture as compared to recommended sole planting of sugar beet.

- Gross income of intercropping cultures $=$ price of sugar beet root yield + price of the top fresh + price of faba bean seed yield + price of faba bean straw yield in Egyptian pound. To calculate the gross income, the average of sugar beet and faba bean prices presented by Bulletin of Statistical Cost Production and Net Return (2018) were used. The sugar beet prices were LE 378.5 ton $^{-1}$ of roots and LE 54 ton $^{-1}$ of top-fresh, meanwhile faba bean prices were LE $805 \mathrm{ardab}^{-1}$ of seed and LE $500 \mathrm{ton}^{-1}$ of straw.

- Net return fed $^{-1}=$ Gross income - Production costs.

- Production costs were LE $5785 \mathrm{fed}^{-1}$ for intercropping culture system (fixed costs of sugar beet + variable costs of faba bean) and LE $5316 \mathrm{fed}^{-1}$ for the sole culture of sugar beet.

\section{Statistical Analysis}

Analysis of variance of data collected of each season was performed. The measured variables were analyzed by ANOVA using MSTAT-C package (Freed, 1991). Mean comparisons were 
performed using the least significant difference (L.S.D) test at 0.05 level of probability (Gomez and Gomez, 1984).

\section{Results and Discussion}

\section{Sugar beet traits}

\section{Physiological traits}

Intercropping faba bean with sugar beet significantly affected total chlorophyll content and leaf area plant ${ }^{-1} 120$ days after sugar beet planting in the two growing seasons (Table, 2). Sugar beet plants grown with faba bean cultivar Misr 1 had higher total chlorophyll content and leaf area plant ${ }^{-1}$ compared with those intercropped with the other faba bean cultivars in the two seasons. Clearly, the adverse effect of intercropping was reduced by growing faba bean cultivar Misr 1 with sugar beet on the same bed. It seems that intercropping faba bean cultivar Misr 1 with sugar beet had lower effect on the dynamics of sugar beet photosynthetic process that was reflected positively on chlorophyll content and thereby sugar beet leaf growth and development compared with faba bean cultivar Sakha 1, Giza 3 'improved' or Giza 843. Total chlorophyll content and leaf area per plant in intercropped sugar beet most likely depend on choice of the suitable faba bean cultivar that connected to a reorganization of the chloroplasts and, hence, a change in the photosystem I (PSI) : photosystem II (PSII) ratio (Anderson et al., 1988).

Table 2: Effect of faba bean cultivars on total chlorophyll content and total leaf area per plant of sugar beet in (2016/2017 and 2017/2018) growing seasons.

\begin{tabular}{|c|c|c|c|c|}
\hline \multirow[b]{2}{*}{ Faba bean cultivar } & \multicolumn{2}{|c|}{$\begin{array}{l}\text { Total chlorophyll content } \\
\left(\mathrm{mg} \mathrm{g}^{-1}\right)\end{array}$} & \multicolumn{2}{|c|}{$\begin{array}{c}\text { Total leaf area } \\
\text { plant }^{-1}\left(\mathrm{~m}^{2}\right)\end{array}$} \\
\hline & $1^{\text {st }}$ season & $2^{\text {nd }}$ season & $1^{\text {st }}$ season & $2^{\text {nd }}$ season \\
\hline Sugar beet + Sakha 1 & 1.69 & 1.81 & 0.55 & 0.68 \\
\hline Sugar beet + Misr 1 & 2.13 & 2.23 & 0.64 & 0.76 \\
\hline Sugar beet + Giza 843 & 1.37 & 1.43 & 0.38 & 0.46 \\
\hline Sugar beet + Giza 3 'Improved' & 1.53 & 1.62 & 0.48 & 0.54 \\
\hline L.S.D. 0.05 & 0.38 & 0.40 & 0.12 & 0.15 \\
\hline
\end{tabular}

\section{Growth, yield and its attributes}

Intercropping faba bean with sugar beet significantly affected on all the studied traits of sugar beet except root diameter and top-fresh weight fed $^{-1}$ in the first season and root weight plant ${ }^{-1}$ in the second season only (Table, 3). Intercropping faba bean cultivar Misr 1 with sugar beet had higher sugar beet yield and its attributes compared with other faba bean cultivars in the two growing seasons. Obviously, growing faba bean cultivar Misr 1 with sugar beet in the same bed reduced the adverse effects of intercropping between them. Intercropping faba bean cultivar Misr 1 with sugar beet had

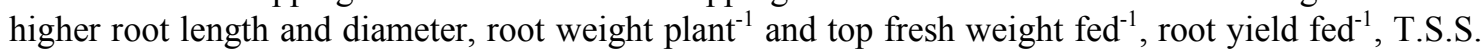
$\%$, sucrose $\%$ and gross sugar yield fed ${ }^{-1}$ than the rest cultivars in the two growing seasons (Table, 3 ). These results probably due to canopy structure and root system of faba bean cultivar Misr 1 was suitable with sugar beet plant to permit more efficient utilization of basic growth resources, which translated into increase in accumulation of dry matter in different organs of sugar beet roots.

Sugar beet alone achieved increment in all characters under study compared with sugar beet under intercropping patterns with different faba bean cultivars in both seasons as shown in Table (3). On the other hand, sugar beet root yield gave the lowest value when intercropped with faba bean Giza 843 variety compared with sugar beet root yield produced with other faba bean verities in both seasons. This result may be due to adverse effect of faba bean Giza 843 variety, which had higher for total leaf area plant $^{-1}$, plant height and number of branches plant ${ }^{-1}$ than other faba bean varieties.

Consequently, canopy and root system architecture of faba bean cultivar Misr 1 was more compatible with sugar beet growth and development to decrease competitive ability between them for available environmental conditions than faba bean cultivars Sakha 1, Giza 843 or Giza 3 'improved'. The plant canopy structure is related to the spatial distribution of its organs above the soil surface (Campbell and Norman, 1989).

These results show that faba bean cultivar Misr 1 stimulated establishment and vegetative growth of sugar beet, and thereby increased root and shoot fresh weights, as well as root length and diameter of sugar beet. 
Certainly, the rhizosphere is a complex environment where roots interact with physical, chemical and biological properties of soil, and is influenced by the presence and activity of root (Richardson et al., 2009).

Table 3: Effect of faba bean cultivars on yield and its attributes, as well as, quality traits of sugar beet in (2016/2017 and 2017/2018) growing seasons

\begin{tabular}{|c|c|c|c|c|c|c|c|c|}
\hline Treatment & 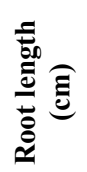 & 冚冚 & 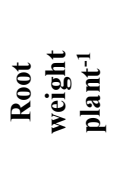 & 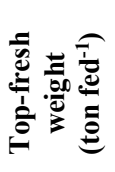 & 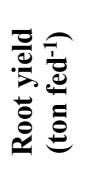 & $\dot{\vec{\varphi}} \vec{\theta}$ & 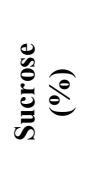 & 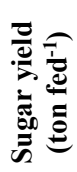 \\
\hline \multicolumn{9}{|c|}{$1^{\text {st }}$ season } \\
\hline \multicolumn{9}{|c|}{ Intercropping culture of sugar beet } \\
\hline Sugar beet + Sakha 1 & 31.63 & 16.47 & 0.84 & 12.04 & 26.35 & 20.88 & 17.42 & 4.59 \\
\hline Sugar beet + Misr 1 & 34.44 & 16.67 & 0.91 & 12.36 & 27.61 & 21.03 & 17.73 & 4.90 \\
\hline Sugar beet + Giza 843 & 28.99 & 16.07 & 0.76 & 11.79 & 22.03 & 19.81 & 16.09 & 3.54 \\
\hline $\begin{array}{l}\text { Sugar beet + Giza } 3 \\
\text { 'Improved' }\end{array}$ & 30.99 & 16.22 & 0.82 & 12.03 & 24.68 & 20.06 & 16.58 & 4.09 \\
\hline L.S.D. 0.05 & 2.22 & NS & 0.06 & NS & 0.97 & 0.80 & 0.66 & 0.33 \\
\hline Sole culture of sugar beet & 37.22 & 18.08 & 1.05 & 14.40 & 30.37 & 21.55 & 18.45 & 5.60 \\
\hline \multicolumn{9}{|c|}{$2^{\text {nd }}$ Season } \\
\hline \multicolumn{9}{|c|}{ Intercropping culture of sugar beet } \\
\hline Sugar beet + Sakha 1 & 33.67 & 19.33 & 0.89 & 15.01 & 27.58 & 21.08 & 17.67 & 4.88 \\
\hline Sugar beet + Misr 1 & 34.18 & 21.07 & 0.95 & 15.13 & 28.30 & 21.25 & 17.98 & 5.09 \\
\hline Sugar beet + Giza 843 & 31.33 & 18.66 & 0.83 & 11.90 & 24.29 & 20.40 & 16.69 & 4.06 \\
\hline $\begin{array}{l}\text { Sugar beet + Giza } 3 \\
\text { 'Improved' }\end{array}$ & 32.00 & 18.99 & 0.88 & 14.00 & 25.81 & 20.78 & 17.22 & 4.45 \\
\hline L.S.D. 0.05 & 1.89 & 1.00 & NS & 0.50 & 1.68 & 1.00 & 0.83 & 0.48 \\
\hline Sole culture of sugar beet & 34.80 & 28.89 & 1.07 & 19.61 & 31.55 & 21.78 & 18.72 & 5.91 \\
\hline
\end{tabular}

These results are in accordance with those obtained by Hamdany and El- Aassar (2017) who found that the highest values for all the studied sugar beet traits were observed in sole planting, followed by intercropping planting, meanwhile intercropping broad bean with sugar beet gave the lowest values for all the studied sugar beet traits except root length in both growing seasons. The highest value of gross sugar yield under intercropping treatments was recorded when sugar beet intercropped with faba bean cultivar Misr 1 followed by sakha 1 in both seasons with values differences of 310 and $210 \mathrm{~kg}$ of gross sugar yield $\mathrm{fed}^{-1}$ in the first and second seasons, respectively.

\section{Faba bean traits}

\section{Physiological traits}

Intercropping faba bean with sugar beet affected significantly on total chlorophyll content and leaf area plant ${ }^{-1}$ after 90 days from faba bean planting in the two growing seasons (Table 4). Intercropping faba bean cultivar Giza 843 with sugar beet had higher total chlorophyll content and leaf area plant ${ }^{-1}$ of faba bean than the rest cultivars in the two growing seasons (Table 4).

Table 4: Total chlorophyll content and total leaf area per plant of faba bean intercropped with sugar beet in (2016/2017 and 2017/2018) seasons.

\begin{tabular}{|c|c|c|c|c|c|}
\hline \multirow[b]{2}{*}{ Cultivar } & \multirow[t]{2}{*}{ Trait } & \multicolumn{2}{|c|}{ Total chlorophyll content $\left(\mathrm{mg} \mathrm{g}^{-1}\right)$} & \multicolumn{2}{|c|}{ Total leaf area plant ${ }^{-1}\left(\mathrm{~cm}^{2}\right)$} \\
\hline & & $1^{\text {st }}$ Season & $2^{\text {nd }}$ Season & $1^{\text {st }}$ Season & $2^{\text {nd }}$ Season \\
\hline Sakha 1 & & 28.71 & 27.82 & 1250.20 & 1199.45 \\
\hline Misr 1 & & 28.36 & 27.41 & 1171.06 & 1124.34 \\
\hline Giza 843 & & 31.14 & 30.21 & 1303.75 & 1280.10 \\
\hline Giza 3 Improved & & 30.38 & 29.28 & 1279.79 & 1243.11 \\
\hline L.S.D. 0.05 & & 2.51 & 2.32 & 50.44 & 78.61 \\
\hline
\end{tabular}

This effect may be due to the differences in genetic effect of the tested faba bean cultivars translated into different morphological and physiological characteristics of faba bean cultivars leaves (Campbell and Norman, 1989). Thus, it is expected that plant height and number of branches per plant 
of Giza 843 cultivar played the main roles. Similar results were reported by Mohamed and El-Abbas (2005), Kandil et al., (2011) and Mohamed et al., (2018) who reported there were significant differences among faba bean cultivars in seed yield and yield attributes traits.

\section{Growth, yield and its attributes traits}

Faba bean cultivars differed significantly in all traits of faba bean except number of branches plant ${ }^{-1}$ under study in both seasons, meanwhile number of pods plant ${ }^{-1}$ was differed significantly among them in the first season only (Table 5). Giza 843 cultivar had higher plant height, number of branches and pods plant ${ }^{-1}$, number of seeds pod ${ }^{-1}, 100$-seed weight, seed yield plant ${ }^{-1}$ and seed and straw yields fed $^{-1}$ followed by Giza 3 'improved' followed by Sakha 1 and the lowest value for these traits were showed with Misr 1 variety in both seasons. This behavior of faba bean varieties was related to pure stands of faba bean varieties. Sharaan et al., (2004) reported the superiority of faba bean cultivar Giza 843 over Misr 1 cultivar for seed weight plant ${ }^{-1}$, seed index, harvest index and seed yield fed ${ }^{-1}$. These results could be due to genteic makeup of faba bean cultivar Giza 843 enhanced vegetative growth efficiency of faba bean plant, which reflected positively on total chlorophyll content and leaf growth and thereby seed filling period compared with the rest cultivars. Some cultivars of faba bean are more suited for planting under shade (Nasrullahzadeh et al., 2007).

Table 5: Growth, yield and its components of intercropped faba bean cultivars in (2016/2017 and 2017/2018) seasons.

\begin{tabular}{|c|c|c|c|c|c|c|c|c|}
\hline $\begin{array}{l}\text { Faba bean } \\
\text { cultivar }\end{array}$ & $\begin{array}{c}\text { Plant } \\
\text { height } \\
(\mathrm{cm})\end{array}$ & $\begin{array}{c}\text { No. of } \\
\text { branches } \\
\text { plant }^{-1}\end{array}$ & $\begin{array}{c}\text { No. of } \\
\text { pods } \\
\text { plant }^{-1}\end{array}$ & $\begin{array}{l}\text { No. of } \\
\text { seeds } \\
\text { pod }^{-1}\end{array}$ & $\begin{array}{c}100- \\
\text { seed } \\
\text { weight } \\
\text { (g) }\end{array}$ & $\begin{array}{c}\text { Seed } \\
\text { yield } \\
\text { plant }^{-1} \\
\text { (g) }\end{array}$ & $\begin{array}{c}\text { Seed yield } \\
\text { (ardab } \\
\left.\text { fed }^{-1}\right)\end{array}$ & $\begin{array}{c}\text { Straw } \\
\text { yield } \\
(\text { ton } \\
\left.\text { fed }^{-1}\right)\end{array}$ \\
\hline \multicolumn{9}{|c|}{$\mathbf{1}^{\text {st }}$ Season } \\
\hline \multicolumn{9}{|c|}{ Intercropping culture of faba bean } \\
\hline Sakha 1 & 114.10 & 3.18 & 8.99 & 2.99 & 65.47 & 16.48 & 3.19 & 0.82 \\
\hline Misr 1 & 111.50 & 3.00 & 8.57 & 2.81 & 63.99 & 15.38 & 2.73 & 0.70 \\
\hline Giza 843 & 121.93 & 3.67 & 9.62 & 3.24 & 70.66 & 19.23 & 3.62 & 0.91 \\
\hline Giza 3 Improved & 120.17 & 3.43 & 9.28 & 3.06 & 68.18 & 17.83 & 3.31 & 0.88 \\
\hline L.S.D. 0.05 & 6.76 & NS & 0.70 & 0.26 & 2.20 & 1.23 & 0.21 & 0.06 \\
\hline \multicolumn{9}{|c|}{ Sole culture of faba bean } \\
\hline Sakha 1 & 118.93 & 2.76 & 8.10 & 2.85 & 52.59 & 10.23 & 8.94 & 2.28 \\
\hline Misr 1 & 111.50 & 2.63 & 7.14 & 2.64 & 51.82 & 9.92 & 8.15 & 2.10 \\
\hline Giza 843 & 120.93 & 3.30 & 8.33 & 3.09 & 57.57 & 12.21 & 10.02 & 2.40 \\
\hline Giza 3 Improved & 120.17 & 3.17 & 8.22 & 2.93 & 55.41 & 11.05 & 9.48 & 2.32 \\
\hline \multicolumn{9}{|c|}{$2^{\text {nd }}$ Season } \\
\hline \multicolumn{9}{|c|}{ Intercropping culture of faba bean } \\
\hline Sakha 1 & 107.40 & 3.07 & 8.73 & 2.69 & 61.38 & 14.05 & 2.72 & 0.67 \\
\hline Misr 1 & 103.19 & 2.80 & 8.34 & 2.67 & 59.67 & 13.36 & 2.53 & 0.62 \\
\hline Giza 843 & 112.65 & 3.33 & 9.40 & 3.12 & 64.88 & 16.53 & 3.35 & 0.85 \\
\hline Giza 3 Improved & 111.11 & 3.20 & 8.90 & 2.90 & 62.63 & 15.47 & 3.12 & 0.80 \\
\hline L.S.D. 0.05 & 5.98 & NS & NS & 0.22 & 1.64 & 1.09 & 0.28 & 0.09 \\
\hline \multicolumn{9}{|c|}{ Sole culture of faba bean } \\
\hline Sakha 1 & 112.73 & 2.71 & 7.89 & 2.57 & 53.05 & 9.98 & 8.08 & 2.06 \\
\hline Misr 1 & 108.02 & 2.48 & 7.68 & 2.44 & 51.24 & 9.63 & 7.70 & 1.94 \\
\hline Giza 843 & 119.03 & 3.10 & 8.68 & 2.92 & 55.45 & 11.94 & 9.44 & 2.31 \\
\hline Giza 3 Improved & 117.70 & 2.96 & 8.26 & 2.70 & 54.07 & 10.96 & 8.79 & 2.26 \\
\hline
\end{tabular}

\section{Competitive relationships}

\section{Land equivalent ratio (LER):}

The values of LER were estimated by using data of recommended sole cultures of both crops. Intercropping faba bean with sugar beet increased LER as compared with sole cultures of both crops in the two growing seasons (Table, 6 ). LER ranged from 1.09 and 1.12 by intercropping faba bean cultivar Giza 843 with sugar beet to 1.24 and 1.23 by intercropping faba bean cultivar Misr 1 with sugar beet in the first and second seasons, respectively. Intercropping faba bean cultivar Misr 1 with sugar beet recorded the highest LER as compared to the others. 
Table 6: Competitive relationships of intercropping some faba bean cultivars with sugar beet in (2016/2017 and 2017/2018) growing seasons.

\begin{tabular}{|c|c|c|c|c|c|c|c|}
\hline \multirow[b]{2}{*}{ Treatment } & \multicolumn{2}{|c|}{$\begin{array}{l}\text { Sugar beet } \\
\text { root yield } \\
\left(\text { ton } / \text { fed }^{-1}\right)\end{array}$} & \multicolumn{2}{|c|}{$\begin{array}{c}\text { Faba bean } \\
\text { seed yield } \\
\left(\text { ardab/fed }^{-1}\right)\end{array}$} & \multirow[t]{2}{*}{$\mathbf{R} \mathbf{Y}_{\mathrm{s}}$} & \multirow[t]{2}{*}{$\mathbf{R} \mathbf{Y}_{\mathbf{f}}$} & \multirow[t]{2}{*}{ LER } \\
\hline & Inter. & Sole & Inter. & Sole & & & \\
\hline \multicolumn{8}{|c|}{$1^{\text {st }}$ Season } \\
\hline $\begin{array}{l}\text { Sugar beet }+ \\
\text { faba bean (Sakha 1) }\end{array}$ & 26.35 & & 3.19 & 8.94 & 0.87 & 0.36 & 1.23 \\
\hline $\begin{array}{l}\text { Sugar beet }+ \\
\text { faba bean (Misr 1) }\end{array}$ & 27.61 & & 2.73 & 8.15 & 0.91 & 0.33 & 1.24 \\
\hline $\begin{array}{l}\text { Sugar beet }+ \\
\text { faba bean (Giza } \\
\text { 843) }\end{array}$ & 22.03 & 30.37 & 3.62 & 10.02 & 0.73 & 0.36 & 1.09 \\
\hline $\begin{array}{l}\text { Sugar beet }+ \\
\text { faba bean (Giza } 3 \\
\text { 'Improved') }\end{array}$ & 24.68 & & 3.31 & 9.48 & 0.81 & 0.35 & 1.16 \\
\hline \multicolumn{8}{|c|}{$2^{\text {nd }}$ Season } \\
\hline $\begin{array}{l}\text { Sugar beet }+ \\
\text { faba bean (Sakha 1) }\end{array}$ & 27.58 & & 2.72 & 8.08 & 0.87 & 0.34 & 1.21 \\
\hline $\begin{array}{l}\text { Sugar beet }+ \\
\text { faba bean (Misr 1) }\end{array}$ & 28.30 & & 2.53 & 7.70 & 0.90 & 0.33 & 1.23 \\
\hline $\begin{array}{l}\text { Sugar beet }+ \\
\text { faba bean (Giza } \\
\text { 843) }\end{array}$ & 24.29 & 31.55 & 3.35 & 9.44 & 0.77 & 0.35 & 1.12 \\
\hline $\begin{array}{l}\text { Sugar beet }+ \\
\text { faba bean (Giza } 3 \\
\text { 'Improved') }\end{array}$ & 25.81 & & 3.12 & 8.79 & 0.82 & 0.35 & 1.17 \\
\hline
\end{tabular}

Table 6: Continued

\begin{tabular}{|c|c|c|c|c|c|c|}
\hline Trait & SPI & $\mathbf{K}_{\mathbf{s}}$ & $\mathbf{K}_{\mathbf{f}}$ & $\mathbf{K}$ & $\mathbf{A}_{\mathbf{s}}$ & $\mathbf{A}_{\mathbf{f}}$ \\
\hline \multicolumn{7}{|l|}{ Treatment } \\
\hline \multicolumn{7}{|c|}{$1^{\text {st }}$ Season } \\
\hline $\begin{array}{l}\text { Sugar beet }+ \\
\text { faba bean (Sakha 1) }\end{array}$ & 37.19 & 1.64 & 2.22 & 3.64 & -0.70 & 0.70 \\
\hline $\begin{array}{l}\text { Sugar beet }+ \\
\text { faba bean (Misr 1) }\end{array}$ & 37.78 & 2.50 & 2.01 & 5.04 & -0.54 & 0.54 \\
\hline $\begin{array}{l}\text { Sugar beet }+ \\
\text { faba bean (Giza } 843 \text { ) }\end{array}$ & 33.00 & 0.66 & 2.26 & 1.49 & -0.90 & 0.90 \\
\hline $\begin{array}{l}\text { Sugar beet }+ \\
\text { faba bean (Giza } 3 \\
\text { 'Improved') }\end{array}$ & 35.28 & 1.08 & 2.15 & 2.33 & -0.73 & 0.73 \\
\hline \multicolumn{7}{|c|}{$2^{\text {nd }}$ Season } \\
\hline $\begin{array}{l}\text { Sugar beet }+ \\
\text { faba bean (Sakha 1) }\end{array}$ & 38.20 & 1.74 & 2.03 & 3.53 & -0.59 & 0.59 \\
\hline $\begin{array}{l}\text { Sugar beet }+ \\
\text { faba bean (Misr 1) }\end{array}$ & 38.67 & 2.18 & 1.96 & 4.26 & -0.52 & 0.52 \\
\hline $\begin{array}{l}\text { Sugar beet }+ \\
\text { faba bean (Giza 843) }\end{array}$ & 35.49 & 0.84 & 2.20 & 1.84 & -0.81 & 0.81 \\
\hline $\begin{array}{l}\text { Sugar beet }+ \\
\text { faba bean (Giza } 3 \\
\text { 'Improved') }\end{array}$ & 37.01 & 1.12 & 2.20 & 2.47 & -0.75 & 0.75 \\
\hline
\end{tabular}

${ }^{*} s=$ Sugar beet \& $f=$ faba bean

These results could be due to competitive ability between sugar beet and faba bean for basic growth resources was differed by the studied faba bean cultivars. It is possible to suggest that canopy structure of faba bean cultivar Misr 1 played a major role in coexistence or compatible with sugar beet, 
which reflected positively on their relative yield. These results are in accordance with those obtained by Abd El-All (2002), Abou Mostafa et al. (2012), El-Dein (2015) and El-Ghobashi and Eata (2020) who showed that intercropping sugar beet with faba bean had the highest LER values compared with sole culture of sugar beet.

\section{System productivity index (SPI):}

SPI indicating higher productivity and stability of intercrops than sole culture. Mean SPI values varied from 33.00 and 35.49 by intercropping faba bean cultivar Giza 843 with sugar beet to 37.78 and 38.67 by intercropping faba bean cultivar Misr 1 with sugar beet in the first and second seasons, respectively (Table, 6). Intercropping faba bean cultivar Misr 1 with sugar beet recorded the highest SPI values, whereas the lowest SPI values were recorded when sugar beet intercropped with faba bean cultivar Giza 843 . This result implies a relatively stable productivity by intercropping faba bean cultivar Misr 1 with sugar beet under intercropping culture.

\section{Relative crowding coefficient (RCC):}

In the present investigation, all values of the RCC were exceeded 1.00 (Table, 6). The lowest RCC was obtained by intercropping faba bean cultivar Giza 843 with sugar beet, which reached 1.49 and 1.84 meanwhile, intercropping faba bean cultivar Misr 1 with sugar beet gave the highest RCC, which reached 5.03 and 4.26 in the first and second seasons, respectively. El-Ghobashi and Eata (2020) revealed that all RCC values were above the unit by intercropping faba bean with sugar beet indicating yield advantage was achieved compared with sole culture of sugar beet. These data reveal that canopy structure of faba bean cultivar Misr 1 was suitable for intercropping with sugar beet, which reflected positively on decrease in the competitive pressure between them. These results are in accordance with those observed by El-Dein (2015) who revealed that relative crowding coefficient in all intercropping of both components exceeded the unit indicating that yield advantage of both components.

\section{Aggressivity (A):}

Aggressivity determines the difference in competitive ability of the component crops in intercropping association. The positive sign indicates the dominant component and the negative sign indicates the dominated component. Higher numerical values of aggressiveness denote greater difference in competitive ability, as well as, bigger difference between actual and expected yield in both crops. The value of Agg of faba bean was positive for all treatments, meanwhile the values of Agg was negative for intercropped sugar beet in the two growing seasons (Table, 6). Results showed that faba bean was the dominant crop and sugar beet was the dominated. El-Dein (2015) and El-Ghobashi and Eata (2020) revealed the same trend.

\section{Economic evaluation}

Farmer's benefit is depended on selecting faba bean cultivar with sugar beet plants. The highest gross income and net return values were recorded with Misr 1 cultivar followed by Sakha 1 cultivar with light differences (Table, 7). Results also showed that the increases in net return reached 13.34 and $5.31 \%$, in the first and second seasons, respectively by intercropping Misr 1 cultivar with sugar beat compared with sole culture of sugar beet, which increases farmer's benefit by LE 926 and 407 per feddan in the first and second seasons, respectively compared with the sole culture of sugar beet.

The results suggest that intercropping faba bean cultivar Misr 1 with sugar beet was more profitable to farmers than sole culture of sugar beet. These findings are parallel with those obtained by El-Dein (2015) who showed that intercropping faba bean with sugar beet was more profitable to farmers than sugar beet sole culture. Also, Ibrahim (2018) showed that the highest total income was obtained by growing sugar beet after soybean and intercropping it with faba bean in hills spaced at $30 \mathrm{~cm}$ in the $1^{\text {st }}$ and $2^{\text {nd }}$ seasons. El-Ghobashi and Eata (2020) confirmed the superiority of intercropping faba bean with sugar beet over the sole culture of sugar beet specially when adding from 70 up to $80 \mathrm{Kg} \mathrm{N}$ fed ${ }^{-1}$ in addition to $30 \mathrm{~m}^{3}$ of farmyard manure. 
Table 7: Economic return of intercropping faba bean cultivars with sugar beet in (2016/2017 and 2017/2018) growing seasons.

\begin{tabular}{|c|c|c|c|c|c|c|c|c|}
\hline \multirow[b]{2}{*}{ Treatment } & \multicolumn{3}{|c|}{$\begin{array}{l}\text { Income of sugar beet } \\
\left(\text { (LE fed }^{-1}\right)\end{array}$} & \multicolumn{3}{|c|}{$\begin{array}{l}\text { Income of faba bean } \\
\left(\mathrm{LE} \mathrm{fed}^{-1}\right)\end{array}$} & \multirow{2}{*}{$\begin{array}{c}\text { Gross } \\
\text { income } \\
\left(\text { LE fed }^{-1}\right)\end{array}$} & \multirow{2}{*}{$\begin{array}{c}\text { Net } \\
\text { return } \\
\left(\mathbf{L E ~ f e d ~}^{-1}\right)\end{array}$} \\
\hline & Root & $\begin{array}{l}\text { Top- } \\
\text { fresh }\end{array}$ & Total & Seed & Straw & Total & & \\
\hline & \multicolumn{8}{|c|}{$1^{\text {st }}$ Season } \\
\hline $\begin{array}{l}\text { Sugar beet }+ \\
\text { faba bean (Sakha 1) }\end{array}$ & 9,960 & 650 & 10,610 & 2,568 & 410 & 2,978 & 13,588 & 7,803 \\
\hline $\begin{array}{l}\text { Sugar beet }+ \\
\text { faba bean (Misr } 1)\end{array}$ & 10,437 & 667 & 11,104 & 2,198 & 350 & 2,548 & 13,652 & 7,867 \\
\hline $\begin{array}{l}\text { Sugar beet }+ \\
\text { faba bean (Giza 843) }\end{array}$ & 8,327 & 637 & 8,964 & 2,914 & 455 & 3,369 & 12,333 & 6,548 \\
\hline $\begin{array}{l}\text { Sugar beet }+ \\
\text { faba bean (Giza } 3 \\
\text { 'Improved') }\end{array}$ & 9,329 & 650 & 9,979 & 2,665 & 440 & 3,105 & 13,084 & 7,299 \\
\hline $\begin{array}{l}\text { Sole culture of sugar } \\
\text { beet }\end{array}$ & 11,480 & 778 & 12,257 & - & - & - & 12,257 & 6,941 \\
\hline & \multicolumn{8}{|c|}{$2^{\text {nd }}$ Season } \\
\hline $\begin{array}{l}\text { Sugar beet }+ \\
\text { faba bean (Sakha 1) }\end{array}$ & 10,425 & 811 & 11,236 & 2,190 & 335 & 2,525 & 13,760 & 7,975 \\
\hline $\begin{array}{l}\text { Sugar beet }+ \\
\text { faba bean (Misr } 1)\end{array}$ & 10,697 & 817 & 11,514 & 2,037 & 310 & 2,347 & 13,861 & 8,076 \\
\hline $\begin{array}{l}\text { Sugar beet }+ \\
\text { faba bean (Giza 843) }\end{array}$ & 9,182 & 643 & 9,824 & 2,697 & 425 & 3,122 & 12,946 & 7,161 \\
\hline $\begin{array}{l}\text { Sugar beet }+ \\
\text { faba bean (Giza } 3 \\
\text { 'Improved') }\end{array}$ & 9,756 & 756 & 10,512 & 2,512 & 400 & 2,912 & 13,424 & 7,639 \\
\hline $\begin{array}{l}\text { Sole culture of sugar } \\
\text { beet }\end{array}$ & 11,926 & 1,059 & 12,985 & - & - & - & 12,985 & 7,669 \\
\hline
\end{tabular}

* Sugar beet prices were LE 378.5 ton $^{-1}$ of roots and LE 54 ton $^{-1}$ of top-fresh, meanwhile faba bean prices were LE $805 \mathrm{ardab}^{-1}$ of seed and LE 500 ton $^{-1}$ of straw.

* Production costs were LE $5785 \mathrm{fed}^{-1}$ for intercropping culture system and LE $5316 \mathrm{fed}^{-1}$ for the culture of sugar beet.

\section{Conclusion}

It could be concluded that intercropping faba bean cultivar MISR-1 at $25 \%$ of the full stand of its sole culture with sugar beet at $100 \%$ density of its sole culture gave highest land equivalent ratio of 1.24 , system productivity index of 38.23 , gross income of LE $13,757 \mathrm{fed}^{-1}$ and net return of LE 7,982 $\mathrm{fed}^{-1}$ for farmers as average of both seasons.

Although faba bean cultivar Misr 1 was more adapted and profitable for farmer more than the rest of tested cultivars and sole culture of sugar beet, however, there is a critical need for several scientific studies including morphological and physiological traits to provide plant breeder information about the most important traits in selection for high yield of faba bean under intercropping with sugar beet.

\section{References}

Abd El-All, A.M., 2002. Weed control treatments for different intercropped systems of sugar beet and faba bean. J. of Agric. Sci., Mansoura Univ., 27: 8081-8092.

Abdel Motagally, F.M.F. and A.K. Metwally, 2014. Maximizing productivity by intercropping onion on sugar beet. Asian Journal of Crop Science, 6: 226-235.

Aboukhadra, S.H., S.A. Badawy, S.E.A. Toaima and D.E.E. El-Shireef, 2013. Effect of intercropping system of faba bean with sugar beet on their productivity and land use. Minufiya J. of Agric. Res., 38: 1501-1518.

Abou Mostafa, R.A.I., E.1. El-Abbas, E.M. Rabie and K.A. Aboshady, 2012. Agronomic and economic evaluation for some patterns of intercropping faba bean with sugar beet under two sowing dates. J. of Agric. Res., Kafrelsheikh Univ., 38: 443-457. 
Anderson, J., W. Chow and D. Goodchild, 1988. Thylakoid membrane organization in sun shade acclimation. Aust. J. Plant Physiol., 15: 11-26.

A.O.A.C., 1990. Official methods of Analysis of the Association of official Agricultural Chemists, $15^{\text {th }}$ Ed. Washington, D.C., U.S.A.

Bulletin of Statistical Cost Production and Net Return, 2018. Winter Field Crops and Vegetables and Fruit, Agriculture Statistics and Economic Sector, Ministry of Egyptian Agriculture and Land Reclamation, Part (1), Egypt.

Campbell, G.S. and J.M. Norman, 1989. The description and measurement of plant canopy structure. In: Russel G, Marshall B and Jarvis PG. (Ed.), Plant canopies: their growth, form and function. Cambridge: Cambridge University Press, 1989. p.1-20.

Carruthers, A. and J.F.T. Oldfield, 1960. Methods for the assessment of sugar beet quality. Int. Sug. J., $63(1): 72-74$

De Wit, C.T., 1960. On competition. Verslagen van Landboukundige Onderzoekingen, 66: 1-82.

El-Dein, A.A.M.Z., 2015. Effect of intercropping some winter crops with sugar beet under different nitrogen fertilizer on yield and its components. Global J. of Agric. and Food Safety Sci., 2: 303318.

El-Ghobashi, Y.E. and A.E.M. Eata, 2020. Competitive relationships and yield advantage of intercropping faba bean with sugar beet under bio-organic additives and mineral nitrogen fertilizer rates. Agric. Sci., 11 (1): 369-389.

Farghaly, B.S., A.A. Zohry and A.A. Bassal, 2003. Crops management for intercropping sugar beet with some essential crops to maximize area unit productivity. J. of Agric. Sci., Mansoura Univ., 28: 5183-5199.

Freed, R.D., 1991. MSTATC Microcomputer statistical program. Michigan State Univ. East Lansing, Michigan, USA.

Gadallah, R.E., A.M. Abdel-Galil and F.R. Nawar, 2006. Maximizing productivity by intercropping some winter crops on sugar beet. J. of Agric. Sci., Mansoura Univ., 31: 4957-4968.

Gomez, K.A. and A.A. Gomez, 1984. Statistical Procedures for Agricultural Research. John Willey and Sons, Inc. New York.

El-Ghobashi, Y.E., and A.E.M. Eata, 2020. Competitive relationships and yield advantage of intercropping faba bean with sugar beet under bio-organic additives and mineral nitrogen fertilizer rates. Agric. Sci., 11, 369-389. DOI: 10.4236/as.2020.114022.

Hamdany, M.Kh. and M.R. El-Aassar, 2017. Effect of intercropping three faba bean varieties with sugar beet plants on piercing sucking insect pests and associated natural enemies under ridge space and seedling rates in relation crop yield. Egypt. Acad. J. Biolog. Sci., 10(6): 57-77.

Ibrahim M.E.M. 2018. Effect of preceding summer crops on yield and quality of sugar beet intercropped with faba bean. J. Plant Prod., Mansoura Univ., 9(1): 59-65.

Kandil A.A., A.E. Sharief and A.S.A. Mahmoud, 2011. Reduction of flower dropping in some faba bean cultivars by growth regulators foliar application. J. Appl. Sci. Res., 7: 1883-1889.

Mead, R. and R.W. Willey 1980. The concept of a "land equivalent ratio" and advantages in yields from intercropping. Exp Agric., 16: 217-228.

Mohamed, H.F.Y., A.A. Mahmoud and E.I. Abdel-Wahab, 2018. Influences of ridge width and foliar spraying of amino acids compounds on yield and quality of two faba bean cultivars. Agricultural Sciences, 9: 1629-1651.

Mohamed, M.R. and E. El-Abbas, 2005. Response of three faba bean cultivars (Vicia faba L.) to different nitrogen sources under P-biofertilizer and micronutrients addition. J. Agric. Sci., Mansoura Univ., 30: 8277-8292.

Mohammed, Wafaa Kh., E.A. El-Metwally and S.A. Saleh, 2005. Intercropping faba bean at different plant densities with sugar beet, Egypt. J. Agric. Res., 83(2): 649-663.

Nasrullahzadeh, S., K. Ghassemi-Golezani, A. Javanshir, M. Valizade and M.R. Shakiba, 2007. Effects of shade stress on ground cover and grain yield of faba bean (Vicia faba L.). J. of Food, Agric. \& Environ., 5(1): 337-340.

Odo, P.E., 1991. Evaluating short and tall sorghum varieties in mixtures with cowpea in Sudan Savanna of Nigeria: LER, grain yield and system productivity index. Exp. Agric., 27: 435-441. 
Richardson, A.E., J.M. Barea, A.M. McNeill and C. Prigent-Combaret, 2009. Acquisition of phosphorus and nitrogen in the rhizosphere and plant growth promotion by microorganisms. Plant and Soil, 321: 305-339.

Salama, Heba S.A., Dina El-S. El-Karamity and A.I. Nawar, 2016. Additive intercropping of wheat, barley, and faba bean with sugar beet: Impact on yield, quality and land use efficiency. Egypt. J. Agron., 38(3): 413-430.

Shao Q., H. Wang, H. Guo, A. Zhou, Y. Huang, Y. Sun and M. Li, 2014. Effects of shade treatments on photosynthetic characteristics, chloroplast ultrastructure, and physiology of Anoectochilus roxburghii. - PLoS ONE 9 (2): 1-10.

Sharaan, A.N., A. Ekram, H.A.S. Megawer and Z.A. Hemida, 2004. Seed yield, yield components and quality character as affected by cultivars, sowing dates and planting distances in faba bean. Bull. Agric. Econ. Min. Agric. Egypt.

Watson, D.J. and M.A. Watson, 1953. Comparative physiological studies on the growth of field crops. III. The effect of infection with beet yellows and beet mosaic viruses on the growth and yield of the sugar beet crop. Ann. App. Biol., 40: 1-37.

Willey, R.W., 1979. Intercropping - its importance and research needs. 1. Competition and yield advantages. Field Crop Abst., 32: 1-10.

Winner C., 1982. Zuckerrubenbau. DLG-Verlags-GmbH, Rusterstrasse 13, D-6000 Frankfurt am Main Germany, 29.

Wettstein, D., 1957. Chlorophyll, Letal und der submikro svopische formmech, sallplastiden. Exptl Cell Ser., 12: 427-433.

Zeidan, M.S., 2002. Effect of sowing dates and urea foliar application on growth and seed yield of determinate faba bean (Vicia faba L.) under Egyptian conditions. Egypt. J. Agron., 24: 93-102. 